\title{
Perspectives
}

\section{Personal Knowledge and the Teaching of Languages}

Garon Wheeler

\section{Introduction}

It is inevitable that we feel we are turning a page as we reach the psychological milestone of the year 2000. It is natural to take stock of our profession, and indeed it can be beneficial. For the most part we will hear predictions of the future of English teaching and optimistic reports on the state of language teaching. Although these will be of interest, I suspect that many of them will have one shortcoming from the point of view of a typical EFL or ESL teacher-a tendency to be out of touch with reality. They will deal with state-ofthe-art teaching, something that is only a dream to the vast majority of teachers around the world. They will appeal to programs that are flexible and open to creativity, where experimentation is welcome. We will in addition almost certainly be introduced to a variety of new techniques and philosophies and hear about the virtues of using computers, the Internet, VCRs, and other hardware. However, having taught languages for 20 years or so, and having been a student of languages for more than 20, I have reached a sobering conclusion: methodology and equipment are not all that important. Too often we are trying to fix something that does not need repairing.

\section{Teaching in the Real World}

Not long ago I participated in the national conference of English teachers in Egypt. Being a native speaker and a professor, I found myself to be a popular figure. "What," I was asked countless times, "is the best way to teach English?" Of course I had no satisfactory answers, which was clearly a disappointment to them. But their belief that there was some magic method that had simply not reached them was distressing, for it was apparent that it caused many of them to believe that they were inadequate teachers. I think that to varying degrees this idea is prevalent among most language teachers. I confess that I have never been involved in or witnessed what could be termed a spectacular achievement in language learning, but I now believe that this is an important lesson: spectacular achievement, if it really exists, is something confined to the pages of journals and pedagogical textbooks. As teachers in the real world, we should concern ourselves with progress that is 
deemed satisfactory by us and our students in the context of their learning, and should not succumb to the suspicion that somehow, if we spent a few extra hours a day in preparation, or were familiar with the newest theories from California or Paris, or had computers for all our students, we could accomplish miracles.

New ideas in teaching languages have appeared with disconcerting regularity in the last few decades. As for methods, for example, we have heard of many of them: Total Physical Response, the Silent Way, Suggestopedia, or Communicative Language Learning, among others. Note that most of them are at least 20 years old. I wager that few of us have ever used any of them to any significant degree. It is not surprising then that, given their age and lack of application, there is now talk of our being in a "postmethod era" (Kumaravadivelu, 1994). More disturbing are the conflicting messages sent by experts in the field. A generation ago one was expected to stress grammar in teaching. Along came a more communicative approach, and explicit grammar instruction was frowned upon. Now it is acceptable again, but please, only in moderation. The nature of educational debate creates a similar fate for nearly any other classroom innovation. What are the best methods of testing? How should we correct written and oral mistakes? Is writing a process or a product? Today's answers may not be the same as tomorrow's. In addition, we always have a surplus of buzzwords. CALLA, content-based instruction, Whole Language, learning and communication strategies, task-based language teaching-these are just a few terms that an up-to-date language teacher has had to absorb in recent times. In the end, though, it is the same story. The primary result of these changes and supposed improvements has often been nothing more than to give conscientious teachers a sense of inadequacy. Nevertheless, it is unlikely that this wave will subside. In fact the number of innovations seems destined to grow indefinitely. This underlines an unsettling weakness in our occupation: instead of being able to zero in on a model of language instruction that is closer and closer to the ideal, we find that our ideas are actually changing at a faster rate than in the past. In addition, advances in technology make it ever harder to stay up to date with "ideal" programs.

There is, I think, something important to learn from this. The problem arises when language teaching is viewed as a science rather than ant. There are too many variables from one class to another and among any group of students. Ausubel (1968), a noted cognitive psychologist, identified at least 18 different cognitive styles; some have found even more. The point here is that the struggle to improve foreign language teaching should and will continue, but the focus of the battle should not, however, be one of finding new methods; rather, it should be a personal one of refining the techniques and controlling the factors that we know or suspect are involved in achieving whatever degree of success we have met with before. The goal is 
to have the confidence to heed one's own knowledge and intuition, even if it conflicts with current popular ideas.

\section{The Importance of Personal Knowledge}

In 1958 Polanyi, a philosopher and academician from the middle of this century, wrote an interesting book entitled Personal Knowledge. The thesis of it is quite simple: Scientific detachment has done a disservice to the social sciences by attempting to eliminate intuition and experience from investigation. Polanyi argued that much of a practitioner's success-that of a teacher in our case-is in fact due to tacit knowledge based on experience. Thus it is possible that the person is unaware of the separate components of this knowledge. What this means is that we, as experienced teachers, know more than we realize. Just because we may be unable to pull out our accumulated language teaching knowledge and analyze it and classify it and describe it does not mean that it is insignificant or defective in any. way. Like many other behaviors, the components of it have been subsumed by a greater whole. What we have is our own knowledge, not exactly like anyone else's, which should not be ignored simply because it does not match what is supposedly correct or the most modern.

This is important because changes in language teaching procedures are often short-lived. It is hard to imagine anyone not coming up with new ideas and approaches-these keep us thinking and reevaluating our own ways of teaching and generally make our professional lives more interesting. However, their overall effect on us is often minimal. One reason is that when it comes to methodology and philosophy of learning, nearly all of us have control over only the minor matters in the classroom. In theory nothing is easier to change than what we do in the classroom, but in practice constraints of all kinds are the norm: a budget, administrators, imposed guidelines, and inflexible syllabi are just a few examples. Just as formidable an obstacle to change, I suspect, is that we know intuitively that any successful technique or method of teaching a language will not be all that different from things we have already seen.

\section{Is Significant Change Really Needed?}

This brings us to the question of whether it is necessary to make drastic changes in the way languages are taught. We generally think so, because it is human nature to worship innovations and technology; we assume that newer is better and that more complicated means more efficient. We pride ourselves on being modern and up to date. It is hard to accept that simpler and old-fashioned may be just as successful as new and modern. It is even harder to accept that we cannot always control or improve something that we know is imperfect. Thus in a high-tech world there is a need to "fix" foreign language teaching. We therefore have one theory after another, one 
more idea to discuss. Have we in fact accomplished anything? Can anyone say that there has been a significant improvement in language pedagogy over the years? In fact language teaching around the world has indeed changed somewhat in recent years, but most notably as there has been a shift in needs: the most noteworthy difference worldwide today compared with even 50 years ago-not a very long time historically-is a need for listening and speaking competence rather than the ability to read and write. Therefore, one true change has been in the goal of language learning. But is this an improvement? No, it is merely a shift in focus, which has come about to meet the reality of changing times. Those who claim, for example, that grammar translation or reading approaches were abandoned as failures-as many methods textbooks do-miss an important point, because these accomplished their goals as well as any other method/philosophy in history. Overall, one may argue, there has been an impressive lack of desired results.

\section{Eight Principles of Good Teaching}

I believe that the desired results are more likely to be attained if one concentrates less on method and technique and more on developing one's own philosophy of successful teaching. I contend that the principles of good language teaching are no different from those of teaching any other subject. With that premise, I would like to compare ideas of good teaching from three great minds from vastly different times and cultures. When we listen to Confucius (5th century BC), Saint Augustine (5th century), and the Arab philosopher Ibn Khaldoun (14th century), we find several basic, recurring themes. When we see that these are also principles advocated by Highet (1949), a respected American educator of half a century ago, and are those with which teachers will most probably agree, it is tempting to conclude that many essential aspects of good teaching have not changed in all of history.

I have found several characteristics of effective teaching that I believe can be found directly or sometimes indirectly in all the writings of these scholars. I have rather arbitrarily grouped them into eight points. First, the effective teacher sets an example of proper conduct. Both Confucius and Highet view this as important not only for producing good citizens, but for instilling a love of learning. Confucius (1943) claims, "When the teacher is respected, people respect what he teaches, and when people respect what he teaches, they respect learning or scholarship" (p. 226; see also Highet, 1949). Related to this is the notion of the importance of a close, positive relationship between the teacher and the students. This will improve the chances that the students will listen (Ibn Khaldoun, chap. VI, sec. 39) and that they will feel free to ask for help (Highet, 1949, p. 168) as well as create a sense of unity. "Togetherness is the essence of teaching," says Highet (p. 57). How does one establish this positive relationship? Patience, they all counsel. Patience is a supreme virtue, according to Augustine, not just in one lesson but long term (chap. V, p. 12). 
In line with this is the need to correct in the proper manner. "As much as possible, correct kindly and gently," says Ibn Khaldoun (chap. VI, sec. 39, p. 307). Highet (1949) advises the use of "gentle steady pressure" (p. 123).

Moving beyond teacher-student dynamics, it is surprising how strongly the scholars stress the need for the teacher to teach the students to think for themselves. The goal is not to force learning, but to provide students with the means to arrive at the answers on their own. Confucius states, "the superior man guides his students but does not pull them along ... he opens the way but does not take them to the place ... [this] makes them think for themselves" (p. 225). In speaking to students, Ibn Khaldoun says, "If you are ... hampered in your understanding ... take refuge in the realm of the natural ability to think given to you by nature! Let your speculation roam ... and let your mind freely delve in it" (chap. VI, sec. 36, p. 297).

Turning to what we would call classroom management, there is quite a bit of advice. Maintaining discipline is important, they agree. It promotes respect not only between the teacher and the students but among the students themselves. (Of course, standards of discipline have changed over the years; for Augustine a good teacher gave only beatings that were well deserved!) A lot is said about the proper method of presenting a lesson. Confucius emphasizes the importance of properly sequenced materials at the right level of difficulty (p. 224). Highet (1949) continually stresses the need for a clear sense of purpose in the classroom (chap. 3). This is done through meticulous planning by the teacher and involves using plenty of concrete examples and ample review. Ibn Khaldoun has the most to say, and it sounds oddly modern (chap. VI, sec. 36, pp. 292-293). Students must be presented with information at least three times. The first is through a survey of the materials to establish what we would now call a schema. The presentation phase is characterized by properly sequenced materials with lots of examples presented in a manner that progresses from the simple to the complex. In his words, understanding is reached when

Little by little ... [the student] faces the problems under consideration and has them repeated and advances from approximate understanding of them to a complete, higher knowledge.... But if a student is exposed to the final results at the beginning, while he is still unable to understand ... he gets the impression that learning is difficult and becomes loath to occupy himself with it. He constantly dodges and avoids it. That is the result of poor instruction, and nothing else. (chap. VI, sec. 36, p. 293)

The final characteristic of good teaching is also clearly the most important, judging by the number of words devoted to it. It is, one could say, the result of the other factors. Presumably, if you set a good example for the students, with whom you have a close, friendly relationship, and display 
unflagging patience and an understanding of the errors of your well-disciplined students as they learn to think for themselves, thanks to just the right material presented at just the right times-the atmosphere in that classroom will be relaxed and highly conducive to learning. In short, all the scholars seem to agree that the psychological factors are the most decisive in determining success. Confucius (1943) says, "If the process of learning is made gentle and easy and the students are encouraged to think for themselves, we may call the man a good teacher" (p. 225). Augustine (1961) states, "We learn better in a free spirit of curiosity than under fear and compulsion. Forcing a student to learn stifles this natural curiosity" (pp. 1,14). Ibn Khaldoun (1958) claims that severity on the part of the teacher "does harm to the students[s] ... it makes them feel oppressed and causes them to lose their energy. It makes them lazy and induces them to lie and be insincere" (chap. VI, sec. 39, p. 305). Highet (1949) puts it this way: "Learning is difficult enough. To add fear to it simply makes it more difficult. Fear does not encourage ... It blocks the movement of the mind" (p. 162).

\section{Conclusion}

These, then, are some principles of good teaching that have been discussed throughout history. This is not intended to imply that they have always found common acceptance; on the contrary, I think their absence in classrooms of the past makes the observations of these philosophers even more impressive. It is principles such as these that should serve as the underpinning of one's activities in the classroom; the methods and techniques should be secondary.

Where does this leave us? What is accepted today as sound pedagogical practice may be rejected tomorrow. Nevertheless, good teaching never really changes. Instead of trying to be trend followers, we are better off going with what works for us, perhaps in spite of expert advice. Because each of us is an individual with varying talents and experiences, it is we who know best what is valid for us in our profession. Our own definition of good teaching should simply be what works best under the circumstances.

Being informed of current issues in our field is a duty. Nevertheless, rather than placing too much faith in what is popular, we should look inside ourselves and consider above all whether we are comfortable with our practices and if they agree with timeless principles. The essence of good teaching is independent of time and place.

\section{The Author}

Garon Wheeler has taught English and linguistics in the United States, Italy, North Africa, and the Middle East. He is the former ESL/EFL director at Huron University in the US and the University of Sharjah in the United Arab Emirates. He now teaches at Zayed University in Abu Dhabi in the UAE. His principal academic interest is the history of linguistics and language teaching, especially the Port-Royal Grammar. He can be reached at garonw@hotmail.com. 
References

Ausubel, D. (1968). Educational psychology-a cognitive view. New York: Holt, Rinehart \& Winston.

Augustine, Saint [of Hippo]. (1961). Confessions. Harmondsworth, UK: Penguin.

Confucius. (1943). The wisdom of Confucius (Wu Yutang, Trans.). New York: Modern Library.

Highet, G. (1949). The art of teaching. New York: Knopf.

Ibn Khaldoun. (1958). The Mugaddimah (vol. 1) (F. Rosenthal, Trans.). New York: Pantheon.

Kumaravadivelu, B. (1994). The postmethod condition: (E)merging strategies for second/foreign language teaching. TESOL Quarterly, 28, 27-48.

Polanyi, M. (1958). Personal knowledge. Chicago, IL: University of Chicago Press. 